\title{
An N-type Naphthalene Diimide Ionene Polymer as Cathode Interlayer for Organic Solar Cells
}

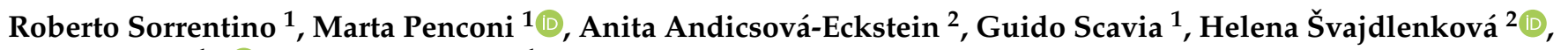 \\ Erika Kozma ${ }^{1, *}$ (D) and Silvia Luzzati ${ }^{1, *}$ \\ 1 Consiglio Nazionale delle Ricerche, Istituto di Scienze e Tecnologie Chimiche "G. Natta", CNR—SCITEC, \\ via A. Corti 12, 20133 Milan, Italy; roberto.sorrentino@scitec.cnr.it (R.S.); marta.penconi@scitec.cnr.it (M.P.); \\ guido.scavia@scitec.cnr.it (G.S.) \\ 2 Polymer Institute, Slovak Academy of Sciences, Dúbravská cesta 9, 84541 Bratislava, Slovakia; \\ anita.andicsova@savba.sk (A.A.-E.); helena.svajdlenkova@savba.sk (H.Š.) \\ * Correspondence: erika.kozma@scitec.cnr.it (E.K.); silvia.luzzati@scitec.cnr.it (S.L.)
}

Citation: Sorrentino, R.; Penconi, M.; Andicsová-Eckstein, A.; Scavia, G.; Švajdlenková, H.; Kozma, E.; Luzzati, S. An N-type Naphthalene Diimide Ionene Polymer as Cathode Interlayer for Organic Solar Cells. Energies 2021, 14, 454. https://doi.org/10.3390/ en14020454

Received: 17 December 2020 Accepted: 12 January 2021 Published: 15 January 2021

Publisher's Note: MDPI stays neutral with regard to jurisdictional clai$\mathrm{ms}$ in published maps and institutional affiliations.

Copyright: (C) 2021 by the authors. Licensee MDPI, Basel, Switzerland. This article is an open access article distributed under the terms and conditions of the Creative Commons Attribution (CC BY) license (https:// creativecommons.org/licenses/by/ $4.0 /)$.

\begin{abstract}
Polymer solar cells (PSCs) based on non-fullerene acceptors have the advantages of synthetic versatility, strong absorption ability, and high thermal stability. These characteristics result in impressive power conversion efficiency values, but to further push both the performance and the stability of PSCs, the insertion of appropriate interlayers in the device structure remains mandatory. Herein, a naphthalene diimide-based cathode interlayer (NDI-OH) is synthesized with a facile threestep reaction and used as a cathode interlayer for fullerene and non-fullerene PSCs. This cationic polyelectrolyte exhibited good solubility in alcohol solvents, transparency in the visible range, selfdoping behavior, and good film forming ability. All these characteristics allowed the increase in the devices' power conversion efficiencies (PCE) both for fullerene and non-fullerene-based PSCs. The successful results make NDI-OH a promising cathode interlayer to apply in PSCs.
\end{abstract}

Keywords: conjugated polyelectrolytes; polymer solar cells; cathode interlayers; interfaces engineering; naphthalene diimide; n-type semiconductor

\section{Introduction}

Polymer solar cells (PSCs) have emerged as a promising renewable energy technology thanks to the low-cost solution processed methods, their characteristic light weight, and the possibility to realize flexible and semitransparent devices [1-4]. Thanks to continuous research efforts spanning from the design of donor and acceptor materials [5] to device architecture [6], in the last year, the power conversion efficiency (PCE) of PSCs has exceeded the incredible value of $18 \%$ [7] in single junction lab-scale device and $10 \%$ in large-area photovoltaic modules [8], improving the differences with other competitive technologies.

After many years spent on optimizing the fullerene acceptor (FA) structure, at present, much attention focuses on non-fullerene acceptor (NFA) materials; these are low band gap materials with easily tunable HOMO-LUMO values and strong absorption in the nearinfrared region [9-12]. The use of new acceptors led to higher performance when compared to FA organic solar cells but, beyond the photoactive film, other fundamental layers in solar cells are the anode interlayer (AIL) and the cathode interlayer (CIL), needed to improve device performance. Indeed, these are an effective tool to optimize charge extraction selectivity and to reduce recombination and contact resistance [13-16]. The increasing number of photoactive materials opens the urgent request to find universal interlayers for PSCs, efficient for a wide range of materials and thickness insensitive [17-19].

Commonly used poly(3,4-ethylenedioxythiophene) polystyrene sulfonate (PEDOT:PSS) represents the benchmark of AILs [20]. On the other hand, CILs received much more attention and various classes of materials have been developed. CILs can be inorganic metal oxides $\left(\mathrm{ZnO}, \mathrm{TiO}_{2}, \mathrm{Al}-\mathrm{ZnO}\right)$ that are robust, but whose optoelectronic properties are 
not easily tunable, and they usually need thermal- and/or light-treatment, which is not suitable for large scale production [21-23]. In contrast to inorganics, the optoelectronic properties of the organic counterpart can be easily tuned by suitable chemical tailoring. They usually have a good film morphology, forming a pinhole-free layer. Among them, notable examples are conjugated polyelectrolytes [24,25]. Conjugated polyelectrolytes like poly [(9,9-bis(3'-(N,N-dimethylamino)propyl)-2,7-fluorene)-alt-2,7-(9,9-dioctylfluorene)] (PFN) are widely used as efficient interlayers both in fullerene and non-fullerene organic solar cells; however, to work efficiently, these must be deposited as ultrathin-films because of their low electron mobility [26-31].

Beside polyfluorenes derivatives, perylene diimides- (PDIs) and naphthalene diimides(NDIs) based compounds have recently received great attention thanks to the possibility to modify the electrodes' work function to easily transport carriers and self-doping behavior [24,25]. PDI polyelectrolytes already work efficiently as CIL in PSCs despite the high absorption in the visible range, [32] but only a few NDI-based polyelectrolytes have been used in NFA-based PSCs [33-36].

With the aim to combine the cathode engineering capability of the PDI polyelectrolytes with higher transmittance in the visible range, we have designed and synthetized a novel NDI-based polyelectrolyte.

Herein, we propose an NDI-based ionene polymer electrolyte (NDI-OH) with an easy three-step synthesis. This compound shows self-doping behavior, and it can be used as a transversal cathode interlayer, working efficiently both with fullerene- and non-fullerenebased solar cells. The polar hydroxyl group, introduced by an anionic exchange reaction, imparts water/alcohol solubility. Remarkably, upon NDI-OH insertion as CIL, both FAand NFA-based PSCs (i.e., PTB7-Th: PC 71 BM and PTB7-Th/ITIC) gained higher PCE with respect to no CIL and equated the optimized PFN and evaporated Ca used as a benchmark. Nevertheless, the NDI-OH interlayer does not suffer for thickness dependence, obtaining stable PCE by increasing the layer thickness in the device.

\section{Materials and Methods}

Materials were obtained from commercial suppliers. 1,4,5,8-naphthalenetetra- carboxylic dianhydride (Sigma Aldrich, Milano, Italy, CAS: 81-30-1), N,N-dimethylethylenediamine (TCI, CAS: 108-00-9), 1,3-dibromopropane (Sigma Aldrich, CAS: 109-64-8), and 4-methoxybenzaldehyde (Sigma Aldrich, CAS: 123-11-5) were used as received. The materials for the active layer or interlayers were obtained from commercial suppliers and used as received ITIC and PFN (1-Material), PTB7-Th (CalOs), and PC 71 BM (Solenne). Solvents N,N-dimethylformamide (DMF, Sigma Aldrich), tetrahydrofurane (THF, Sigma Aldrich), diethylether (Lachner), and acetone (Lach:ner) were used without further purification. The anion exchange was performed using a hydroxide anion exchange resin, Amberlite ${ }^{\circledR}$ IRN78, Aldrich (CAS: 11128-95-3).

NMR spectra $(1 \mathrm{H}$ at $400 \mathrm{MHz}$ ) were recorded on a Inova Varian NMR spectrometer equipped with a $5 \mathrm{~mm}$ ATB 1H/19F/X PFG Broadband Probe using standard pulse sequence and $\mathrm{D}_{2} \mathrm{O}$ or $\mathrm{CDCl}_{3}$ as a solvent.

The molar masses of the polymers were performed on Shimadzu system equipped with an RI detector, using a two-column configuration $(8 \times 300 \mathrm{~mm}$ PFG-type columns with $7 \mu \mathrm{m}$ and porosity of $1000 \AA$ and $100 \AA$, provided by Polymer Standards Services $\mathrm{GmbH}$, Mainz, Germany). The system was operated in 2,2,2-trifluorethanol (TFE) at a flow rate of $1 \mathrm{~mL} / \mathrm{min}$ and RT. PMMA (Polymer Standards Services GmbH, Mainz, Germany) calibration was used.

The absorption spectra were recorded using a Perkin Elmer Lambda 900 spectrometer.

PL measurements were performed on a modified NanoLog-TCSPC (Horiba) with a monochromated Xenon lamp excitation source. All the PL spectra are corrected for the instrument response and measured in the backscattering mode in air at room temperature.

ATR-FTIR spectra were obtained on a spectrophotometer Nicolet 8700 (Thermo Fisher Scientific, Madison, WI, USA) using KBr, with a deuterated triglycine sulfate and thermo- 
electricity cooled (DTGS TEC) detector in the region of $4000-600 \mathrm{~cm}^{-1}$ at a resolution of $4 \mathrm{~cm}^{-1}$ using the absorbance mode.

The EPR analysis was made using Bruker WinEPR Processing (Billerica, MA, USA). The measurements were performed on a comparable amount $(10.5 \mathrm{mg})$ of polyelectrolyte in the solid state and measured at RT and after heat treatment. The samples were heated to $120^{\circ} \mathrm{C}$ for $1 \mathrm{~h}$ in the presence of argon.

The experimental conditions had an X-band frequency of $9.12 \mathrm{GHz}$, a power of $1 \mathrm{~mW}$, Gain 20, and a temperature of $25^{\circ} \mathrm{C}$.

Cyclic voltammetry measurements were performed with a laboratory potentiostat/galvanostat Autolab PGSTAT 302N with an impedimetric module (Ecochemie, Utrecht, The Netherlands). A three-electrode system consisted of $\mathrm{Ag} / \mathrm{AgCl} / 3 \mathrm{M} \mathrm{KCl}$ reference electrode, a counter Pt electrode (Bioanalytical systems, USA), and the glassy carbon $(d=3 \mathrm{~mm})$ as a working electrode (ProSense B.V., The Netherlands) was applied. All cyclic voltammetry (CV) measurements were recorded at a sweep rate of $100 \mathrm{mV} \mathrm{s}^{-1}$. The electrochemical procedures were run under Nova Software 1.10, and the acquired data were evaluated using OriginPro 9.1. For analysis, tetrabutyl-ammonium hexafluorophosphate $\left(\mathrm{Bu}_{4} \mathrm{NPF}_{6}\right.$, $0.1 \mathrm{M}$ ) in acetonitrile and polyelectrolyte with concentration $0.1 \% w / w$ was used. Ferrocene was used as the internal standard.

Atomic force microscopy (AFM) measurements were performed using a commercial AFM (NTMDT NTEGRA) used in tapping mode with a cantilever NSG10 operating at a typical resonance frequency of $140-390 \mathrm{kHz}$. The deposition of the films was identical to device fabrication. The thicknesses of the layers were obtained using a Bruker Dektak stylus profiler. All the reported values are the average of five measurements in different areas of the layer to check the uniformity of the deposited films. For the fabrication of PSCs, glass substrates $\left(25 \times 25 \times 1.1 \mathrm{~mm}^{3}\right)$ coated with indium tin oxide (ITO) with a sheet resistance of $15 \Omega$ /sq were used. After mechanical cleaning with fiberless paper, the substrates were sonicated at $50{ }^{\circ} \mathrm{C}$ in water, acetone, and finally in 2-propanol for $10 \mathrm{~min}$ each step. After being dried with an $\mathrm{N}_{2}$ gun, the substrates were treated in ozone plasma for $2 \mathrm{~min}$. Immediately after the plasma treatment, a solution of PEDOT:PSS (Heraeus, Al 4083) is filtered by using a $0.45 \mu \mathrm{m}$ PVDF filter and deposed on ITO to obtain a $35 \mathrm{~nm}$ thick layer by spin coating ( $3500 \mathrm{rpm}, 60 \mathrm{~s}$ ). The films were thermally annealed at $150{ }^{\circ} \mathrm{C}$ for $10 \mathrm{~min}$. After cooling down the substrates, a layer of active material was spin coated inside an $\mathrm{N}_{2}$-filled glovebox. PTB7-Th and $\mathrm{PC}_{71} \mathrm{BM}$ were dissolved at a composition of 1:1.5 weight ratio in chlorobenzene, with a solute concentration of $25 \mathrm{mg} / \mathrm{mL}$. This solution was stirred overnight at $65^{\circ} \mathrm{C}$. Next, $10 \mathrm{~min}$ after adding $2 \% v / v$ of 4 -methoxybenzaldehyde to the solution, the blend was spin coated at $1200 \mathrm{rpm}$ in order to obtain films with a thickness of $100 \mathrm{~nm}$. The samples were left at room temperature for $10 \mathrm{~min}$ and then annealed for $20 \mathrm{~min}$ at $60^{\circ} \mathrm{C}$. PTB7-Th and ITIC were dissolved at a composition of 1:1.2 weight ratio in a $20 \mathrm{mg} / \mathrm{mL}$ chlorobenzene solution and stirred overnight at $65^{\circ} \mathrm{C}$. The blend films were spin coated at $1500 \mathrm{rpm}$ and annealed for $10 \mathrm{~min}$ at $120^{\circ} \mathrm{C}$, obtaining a film with $100 \mathrm{~nm}$ thickness. The NDI-OH was dissolved in $\mathrm{MeOH}$ with a concentration of $1 \mathrm{mg} / \mathrm{mL}$ and the deposition on top of the active layer is done by spin coating at different spin speeds (from 1000 to $4500 \mathrm{rpm}$, obtaining from ca. $35 \mathrm{~nm}$ to less than $10 \mathrm{~nm}$ of CIL). The PFN was dissolved at $0.2 \mathrm{mg} / \mathrm{mL}$ in methanol, with the addition of $0.25 \% v / v$ of acetic acid, to obtain CIL films of ca. $5 \mathrm{~nm}$ upon spin coating. The metal cathode consisting of $80 \mathrm{~nm}$ of Ag layer or Ca $(10 \mathrm{~nm}) / \mathrm{Ag}$ was finally thermally evaporated in high vacuum (8.10-7 bar) with a metal evaporator. The final device area is $6.1 \mathrm{~mm}^{2}$.

The current density-voltage measurements were performed in glovebox with a Keithley 2602 source meter under AM 1.5 G solar simulation (ABET 2000).

External quantum efficiency (EQE) spectral responses were recorded by dispersing an Xe lamp through a monochromator, using a Si solar cell with calibrated spectral response to measure the incident light power intensity at each wavelength. The devices were taken outside the glovebox for the EQE measurements, after mounting them on a sealed cell to avoid moisture and oxygen exposure. 


\section{Results and Discussion \\ Material Synthesis and Characterization}

The synthesis of NDI-based ionene polymer is shown in Figure 1. The polymer is obtained through a quaternization reaction without the use of metallic catalysts, which is extremely important for ultimate applications in organic electronic devices. The resultant cationic polymer NDI-OH is a polyelectrolyte containing the charged units within the polymer backbone, assuring higher ionic density with respect to polymers containing pendant ionic moieties [37]. Moreover, it is soluble in alcohol, and thus it can be spin coated from orthogonal solvents with respect to the active layer.
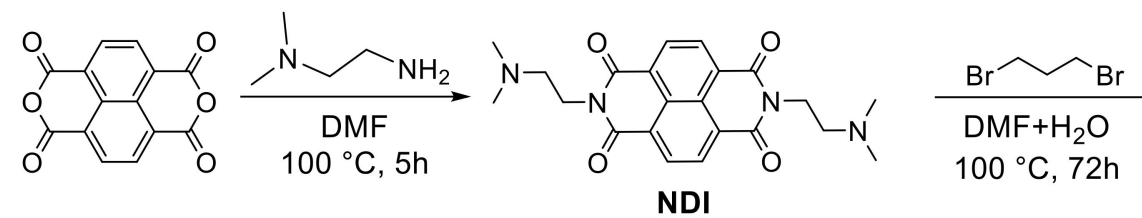

NDI $100^{\circ} \mathrm{C}, 72 \mathrm{~h}$
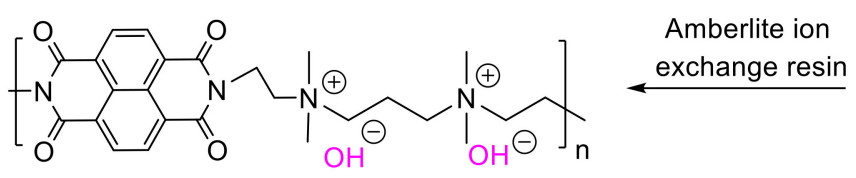

$\mathrm{NDI}-\mathrm{OH}$

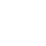

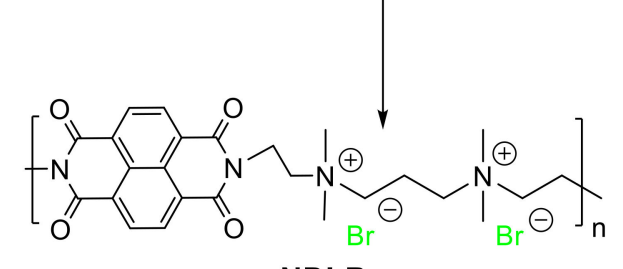

$\mathrm{NDI}-\mathrm{Br}$

Figure 1. Three-step synthesis of naphthalene diimide-based cathode interlayer (NDI-OH).

Synthesis of NDI. N, N-dimethylethylenediamine $(2.5 \mathrm{~mL}, 22.5 \mathrm{mmol})$ was added to a solution of 1,4,5,8-naphthalenetetracarboxylic dianhydride ( $2.5 \mathrm{~g}, 9.3 \mathrm{mmol})$ in DMF $(30 \mathrm{~mL})$. The reaction mixture was heated to $130{ }^{\circ} \mathrm{C}$ for $5 \mathrm{~h}$ and then the solvent was removed under reduced pressure. The residue was purified by precipitation (three times) into THF and diethyl ether to give NDI-N in $74 \%$ yield. ${ }^{1} \mathrm{H}$ NMR $\left(400 \mathrm{MHz}, \mathrm{CDCl}_{3}\right), \delta$ (ppm): $8.75(\mathrm{~s}, 4 \mathrm{H}), 4.34(\mathrm{t}, 4 \mathrm{H}), 2.67(\mathrm{t}, 4 \mathrm{H}), 2.34(\mathrm{~s}, 12 \mathrm{H})$.

Synthesis of NDI-Br. To the previously prepared NDI (1.4 g, $3.4 \mathrm{mmol}$ ), 1,3-dibromopropane $(0.68 \mathrm{~g}, 3.4 \mathrm{mmol})$ and DMF $(40 \mathrm{~mL})$ was added. After bubbling with Ar for $20 \mathrm{~min}$, the reaction mixture was heated to $100{ }^{\circ} \mathrm{C}$ for $72 \mathrm{~h}$. During the reaction $5 \mathrm{~mL}$ water was added gradually every $12 \mathrm{~h}$. Then the reaction was cooled down, followed by the evaporation of water. The mixture was then precipitated into THF. Subsequently, the precipitate was collected and was extracted by acetone, ethanol, and water. The water fraction was then collected and precipitated into THF. The collected brown solid was then dried under a vacuum. The obtained product $(1.5 \mathrm{~g})$ was kept under argon. ${ }^{1} \mathrm{H}$ NMR $\left(400 \mathrm{MHz}, \mathrm{D}_{2} \mathrm{O}\right)$, $\delta(\mathrm{ppm}): 8.52(\mathrm{~m}, 4 \mathrm{H}), 4.61(\mathrm{~m}, 4 \mathrm{H}), 3.85(\mathrm{~m}, 4 \mathrm{H}), 3.46(\mathrm{~s}, 12 \mathrm{H}) .2 .67-2.60(\mathrm{~m}, 8 \mathrm{H})$; GPC (TFE): $\mathrm{Mw}=9.6 \mathrm{kDa}, \mathrm{Mn}=4.8 \mathrm{kDa}$.

Synthesis of NDI-OH. A column of hydroxide anion exchange resin Amberlite ${ }^{\circledR}$ IRN78 was first flushed with pure water and then NDI-Br $(8 \mathrm{mg} / \mathrm{mL}$ water) solution was slowly passed through the column. The collected water solution was lyophilized. The isolated NDI-OH was kept under argon. ${ }^{1} \mathrm{H}$ NMR $\left(400 \mathrm{MHz}, \mathrm{D}_{2} \mathrm{O}\right), \delta(\mathrm{ppm}): 8.40(\mathrm{~m}, 4 \mathrm{H})$, $4.43(\mathrm{~m}, 4 \mathrm{H}), 3.73(\mathrm{~m}, 4 \mathrm{H}), 3.34$ (s, $12 \mathrm{H}), 2.38-2.32(\mathrm{~m}, 8 \mathrm{H})$; GPC (TFE): $\mathrm{Mw}=1.6 \mathrm{kDa}$, $\mathrm{Mn}=1.1 \mathrm{kDa}$.

Cyclic voltammetry (CV) measurements were carried out to determine the HOMOLUMO energy levels. As shown in Figure S1, the reduction potential onset $\left(\mathrm{E}^{\mathrm{on}}{ }_{\mathrm{red}}\right)$ for $\mathrm{NDI}-\mathrm{OH}$ is $-0.70 \mathrm{~V}$. From the empirical formula $\mathrm{E}_{\mathrm{LUMO}}=-\mathrm{e}\left(\mathrm{E}_{\mathrm{red}}-\mathrm{E}_{\mathrm{ferr}}\right)+4.8 \mathrm{eV}$ and $\mathrm{E}_{\mathrm{HOMO}}=\mathrm{E}_{\mathrm{g}}{ }^{\text {opt }}+\mathrm{E}_{\mathrm{LUMO}}$, the HOMO and LUMO energy levels of NDI-OH are calculated to be $-6.80 \mathrm{eV}$ and $-3.69 \mathrm{eV}$, respectively.

The optical properties of NDI-OH as solid film were investigated by UV-Vis absorption spectroscopy. As depicted in Figure 2a, NDI-OH exhibits a broad absorption with a peak centered at $361 \mathrm{~nm}$, which is assigned to the $\pi-\pi^{*}$ transition of the NDI's units. The 
absorption spectrum exhibits a tail above $400 \mathrm{~nm}$ that might be a hint of the presence in NDI-OH films of some delocalized radical anions due to a self-doping effect; i.e., an electron is transferred from the ionic moiety to the naphtalene units [35]. Upon thermal annealing under $\mathrm{N}_{2}$ atmosphere for $10 \mathrm{~min}$ at $120^{\circ} \mathrm{C}$, a radical anion signature at $450 \mathrm{~nm}$ is observed [38], suggesting an increased electron transfer ability. The IR absorption spectrum of the NDI-OH film (Figure S2) also shows some modifications, such as a decrease in the NDI's $\mathrm{C}=\mathrm{O}$ modes and enhancement of the ring modes oscillator strengths after thermal treatment that are consistent with NDI's radical anions formation.

Electron paramagnetic resonance (EPR) spectroscopy measurements were conducted to further investigate the interaction between the ionic moieties and naphthalene units in solid state. The results are reported in Figure 2b. After heat treatment, the singlet of NDI-OH sample increased its intensity, which confirms the higher self-doping ability. Note that in the solid state, an enhancement of the self-doping ability after a thermal treatment under a dry atmosphere was already observed in a perylene diimide- (PDI)based electrolyte bearing $-\mathrm{N}\left(\mathrm{CH}_{3}\right)_{3}{ }^{+} \mathrm{OH}^{-}$polar groups [39]. With PDIs, this effect was ascribed to a dehydration of the $-\mathrm{N}\left(\mathrm{CH}_{3}\right)_{3}{ }^{+} \mathrm{OH}^{-}$group, which favors the electron transfer from the $\mathrm{OH}^{-}$to PDIs. The same effect can reasonably occur also in NDI-OH. Such dehydration is triggered by the thermal treatment, but might also naturally occur in the drybox, where the solar cells are assembled and tested.
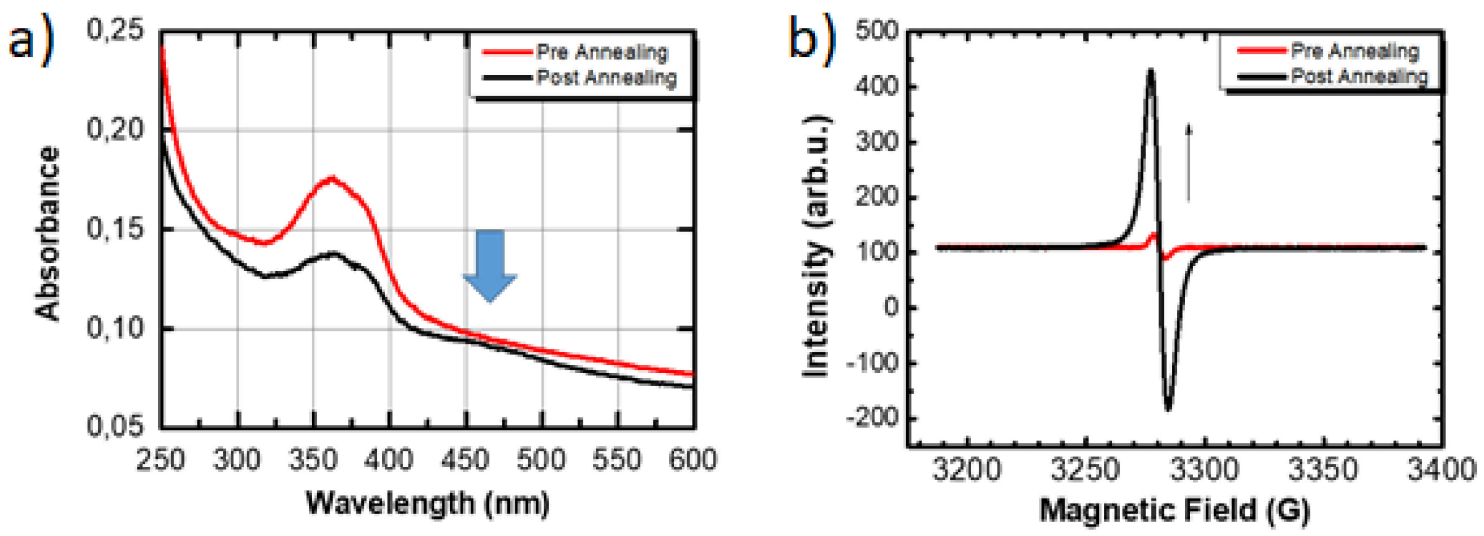

Figure 2. (a) UV-Vis absorption spectra of NDI-OH films and (b) electron paramagnetic resonance (EPR) pre-annealing (red curve) and post-annealing (black curve).

To understand whether NDI-OH has suitable properties for use as cathode interlayer in PSCs, we probed its energy level alignment to the $\mathrm{PC}_{71} \mathrm{BM}$ and ITIC acceptors by steady state photoluminescence measurements (PL) (Figure S3). For these experiments, the photoluminescence of the acceptor films here under study were recorded with a thin layer of NDI-OH deposited on top of the acceptor. For comparative studies, thin layers of PFN were also used. The PL spectra of ITIC are reduced in intensity when in contact to the NDI-OH interlayer when compared to the PFN. This suggests that an electron transfer from the ITIC to the interlayer is facilitated with NDI-OH.

With the NFA, the lower LUMO level of NDI-OH $(-3.69 \mathrm{eV})$ compared to PFN $(-2.14 \mathrm{eV})$ forms a better energy-level alignment at the cathode interface with ITIC (LUMO $-3.78 \mathrm{eV}$ ). Indeed, a smaller energy offset between ITIC and NDI-OH compared to PFN, facilitates the electron transfer which is clearly demonstrated by the ITIC PL quenching in the NDI-OH/ITIC films. Moreover, the low-lying HOMO value of $-6.80 \mathrm{eV}$ for NDI-OH means that holes from various donors will be blocked sufficiently at the cathodes, with the NDI-OH derivative used as CIL.

This is not the case for $\mathrm{PC}_{71} \mathrm{BM}$ in contact with PFN or NDI-OH, in which the PL spectra seems pretty similar. Even though the $\mathrm{PC}_{71} \mathrm{BM}$ exhibits a relatively low intensity, 
such behavior is anyhow different from the ITIC one. This might arise from a higher energy offset that hinders the electron transfer from the $\mathrm{PC}_{71} \mathrm{BM}$ to both the interlayers.

These results encouraged us to explore NDI-OH as a cathode interlayer not only in FA-PSCs, but also in NFA-PSCs, where having a good energy level alignment among the acceptor and the interlayer is particularly important [40].

We fabricated conventional devices with a structure of ITO/PEDOT:PSS/Active Layer/NDI-OH/Ag, as shown in Figure 3. The active layer contains PTB7-Th as the donor component and fullerene $\left(\mathrm{PC}_{71} \mathrm{BM}\right)$ or non-fullerene (ITIC) as acceptors. Figure 3 shows the chemical structures of the photoactive materials.

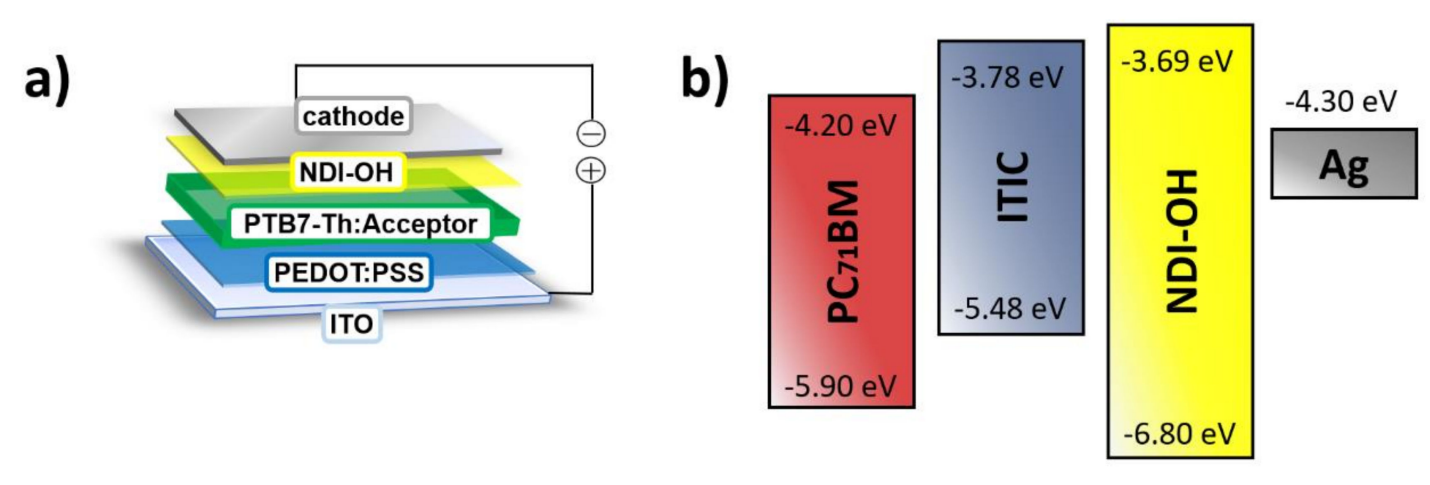

\section{c)}

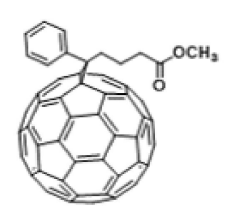

$\mathrm{PC}_{71} \mathrm{BM}$
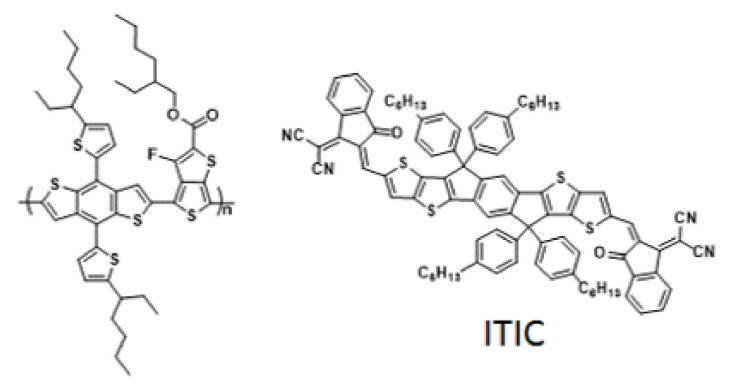

ITIC

PTB7-Th

Figure 3. (a) Device architecture (b) energy level and (c) structures of polymers and molecules used as active layers.

To investigate the NDI-OH performance in PSCs, some reference CIL have been chosen. The NDI-OH layer has been compared with no IL and some benchmarks in the literature such as evaporated Calcium (Ca) and spin coated PFN by using the same solar cell geometry.

The photovoltaic performances of the fabricated PSCs were evaluated under AM $1.5 \mathrm{G}$ solar simulation at one sun $\left(100 \mathrm{~mW} \mathrm{~cm}^{-2}\right)$. The $\mathrm{J}-\mathrm{V}$ curves of the devices in light conditions are shown in Figure 4 and their PV characteristics are resumed in Tables 1 and 2 for clarity. The external quantum efficiency (EQE) spectra are measured on the best devices obtained and shown in Figure 4b,d.

Table 1. Figures of merit for fullerene-based polymer solar cells (PSCs). Active layer PTB7-Th+ PC 71 BM.

\begin{tabular}{|c|c|c|c|c|c|c|}
\hline $\begin{array}{c}\text { Active Layer: } \\
\text { PTB7-Th + } \\
\text { PC }_{71} \text { BM }\end{array}$ & $\begin{array}{l}\mathrm{V}_{\mathrm{OC}} \\
{[\mathrm{V}]}\end{array}$ & $\begin{array}{c}\mathrm{JSC}_{\mathrm{SC}} \\
{\left[\mathrm{mA} / \mathrm{cm}^{2}\right]}\end{array}$ & $\begin{array}{l}\text { FF } \\
{[\%]}\end{array}$ & $\begin{array}{c}\mathrm{PCE}_{\max } / \\
\text { PCE }_{\text {avg }}[\%]\end{array}$ & $\begin{array}{c}\mathbf{R}_{\mathrm{S}} \\
{\left[\Omega \mathrm{cm}^{-2}\right]}\end{array}$ & $\begin{array}{c}\mathrm{R}_{\mathrm{SH}} \\
{\left[\mathrm{k} \Omega \mathrm{cm}^{-2}\right]}\end{array}$ \\
\hline NDI-OH/Ag & 0.74 & 14.48 & 58 & $6.19(5.86)$ & 8.76 & 832.63 \\
\hline $\mathrm{PFN} / \mathrm{Ag}$ & 0.73 & 14.16 & 64 & $6.60(6.40)$ & 6.43 & 721.58 \\
\hline $\mathrm{Ag}$ & 0.66 & 14.51 & 61 & $5.85(5.72)$ & 8.12 & 591.12 \\
\hline
\end{tabular}


Table 2. Figures of merit for non-fullerene-based PSCs. Active layer PTB7-Th + ITIC.

\begin{tabular}{|c|c|c|c|c|c|c|}
\hline $\begin{array}{c}\text { Active Layer: } \\
\text { PTB7-Th + ITIC }\end{array}$ & $\begin{array}{l}\mathrm{V}_{\mathrm{OC}} \\
{[\mathrm{V}]}\end{array}$ & $\begin{array}{c}\mathrm{JSC}_{\mathrm{SC}} \\
{\left[\mathrm{mA} / \mathrm{cm}^{2}\right]}\end{array}$ & $\begin{array}{c}\text { FF } \\
{[\%]}\end{array}$ & $\begin{array}{c}\text { PCE }_{\max } / \\
\text { PCE }_{\text {avg }}[\%]\end{array}$ & $\begin{array}{c}R_{S} \\
{\left[\Omega \mathrm{cm}^{-2}\right]}\end{array}$ & $\begin{array}{c}R_{\mathrm{SH}} \\
{\left[\mathrm{k} \Omega \mathrm{cm}^{-2}\right]}\end{array}$ \\
\hline NDI-OH/Ag & 0.79 & 13.79 & 51 & $5.51(5.06)$ & 15.07 & 471.91 \\
\hline $\mathrm{PFN} / \mathrm{Ag}$ & 0.73 & 14.09 & 51 & $5.29(5.04)$ & 12.97 & 380.09 \\
\hline $\mathrm{Ag}$ & 0.58 & 13.42 & 46 & $3.56(3,38)$ & 15.64 & 221.99 \\
\hline $\mathrm{Ca} / \mathrm{Ag}$ & 0.79 & 12.84 & 54 & $5.47(5.40)$ & 13.17 & 578.78 \\
\hline
\end{tabular}

For both FA and NFA PSCs, the use of NDI-OH as CIL brings better device performance in comparison with those without IL and improved or similar performance with devices containing PFN.

a)

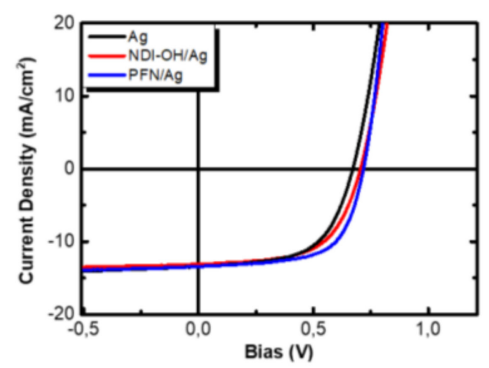

b)

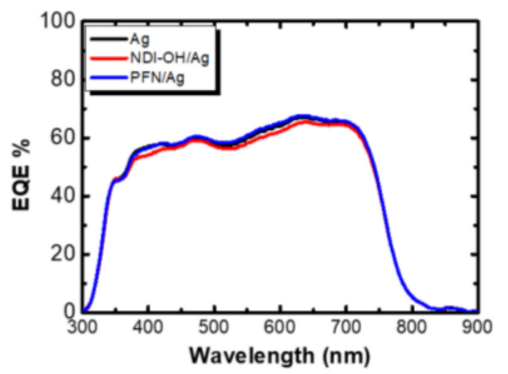

c)

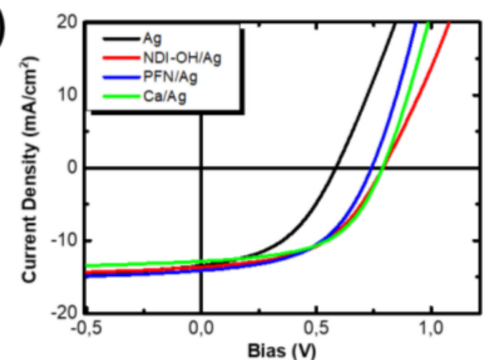

d)

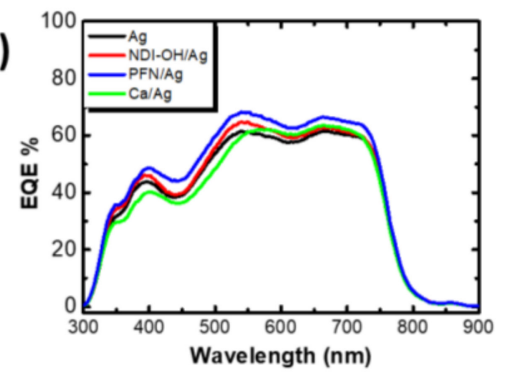

Figure 4. J-V characterization and external quantum efficiency (EQE) of the devices. PTB7-Th+ $\mathrm{PC}_{71} \mathrm{BM}$ with different interlayers (none, NDI-OH and PFN) (a) J-V and (b) EQE. PTB7-Th+ITIC with different interlayers (none, NDI-OH, PFN and Ca) (c) J-V and (d) EQE.

For fullerene-based PSCs, the use of NDI-OH as CIL provides encouraging results. The devices' performances are similar to those obtained with the PFN benchmark and exhibits an improvement compared to the interlayer-free device. Indeed, the presence of the IL permits to enhance $\mathrm{V}_{\mathrm{OC}}$ from $0.66 \mathrm{~V}$ without $\mathrm{CIL}$ to 0.73 and $0.74 \mathrm{~V}$ in the case of PFN and NDI-OH, respectively.

When NFA-based solar cells are studied, the PCE enhancement upon IL addition is relevant. The comparison between the different interlayers is shown in Figure 4c. The $\mathrm{V}_{\mathrm{OC}}$ is improved from $0.58 \mathrm{~V}$ without CIL to $0.73 \mathrm{~V}$ for PFN and $0.79 \mathrm{~V}$ in the case of $\mathrm{Ca}$ and NDI-OH.

A common feature for FA and NFA PSCs is the increase in $\mathrm{V}_{\mathrm{OC}}$ when NDI-OH is used as an interlayer, thanks to the enhanced built-in voltage, as shown with the dark J-V curves of the devices in Figure S4 [41]. This behavior is typical for polar/ionic organic semiconductors interlayers and it is due to the cationic groups of NDI-OH, forming dipoles at the active layer/electrode interface, that induce an up-shift of the cathode electrode work function [26,42]. This is unable to enhance the electron selectivity of the Ag electrode, leading to an improvement of the Voc parameter. Such enhancement of the Voc by the insertion of the NDI-OH interlayer is particularly noticeable in NFA PSCs. This is because the increase in the Ag cathode electrode's selectivity imparted by the interlayer is becoming particularly important when using ITIC as an acceptor, due to its lower LUMO level as compared to fullerene. 
Interestingly, the photovoltaic performance of the NDI-OH based NFA PSCs exhibit good tolerance to the NDI-OH thickness variation in fabricating the OSC devices, which is important for large area fabrication of the OSCs. While the commonly used PFN CIL works well with very thin thicknesses [43], when the NDI-OH thickness rises up to $35 \mathrm{~nm}$, the PCE of the devices has very small variations and maintains values around 5\% (Table S1). Impressively, the $\mathrm{V}_{\mathrm{OC}}$ still maintains a high value of $0.76-0.77 \mathrm{~V}$ when the NDI-OH thickness is further increased to $35 \mathrm{~nm}$, indicating a good electron-transport and collection ability of the NDI-OH CIL. Table S1 shows the effect of CIL thickness on the photovoltaic performance of the NDI-OH-based OSCs. The PCE decreased from 5.22\% for the optimized device with NDI-OH thickness of $<10 \mathrm{~nm}$ to $4.73 \%$ for the OSC with NDI-OH thickness of $35 \mathrm{~nm}$.

From the above findings, we can safely conclude that NDI-OH interlayer exhibits the right PV functionality to increase the Ag electrode selectivity and enables a suitable energy level alignment at the NFA/IL interface. Moreover, the NDI-OH also function as an electron transport layer, as supported by the good tolerance to the NDI-OH thickness variation. These factors contribute to a reduction in the contact resistance at both interfaces and favor charge extraction. In this condition, we would expect an increase in the FF parameter and a reduction in the series resistance (Rs).

As shown in Table 2, the FF is indeed increasing by NDI-OH IL, but no changes are observed in the series resistance. Furthermore, as depicted in Table 1, when going to FA devices, the Rs also stays unmodified and the FF is not improving.

To get some insight, we performed atomic force microscopy (AFM) analysis, shown in Figure 5. From these images, it is possible to appreciate the different morphology between PFN and NDI-OH, compared with the bare active layer. Reported on the images, the RMS values are almost identical and lower than $1.5 \mathrm{~nm}$, meaning a good film-forming ability and a complete coverage of the CILs on the photoactive blend. Small holes can be identified in NDI-OH layer, meaning a slight dewetting of the layer. This dewetting might reduce the quality of the interfaces, thus affecting the Rs. We suppose that the same dewetting is present also when NDI-OH is deposited onto $\mathrm{PC}_{71} \mathrm{BM}$ and this could be consistent with the slight FF reduction reported in Table 1.
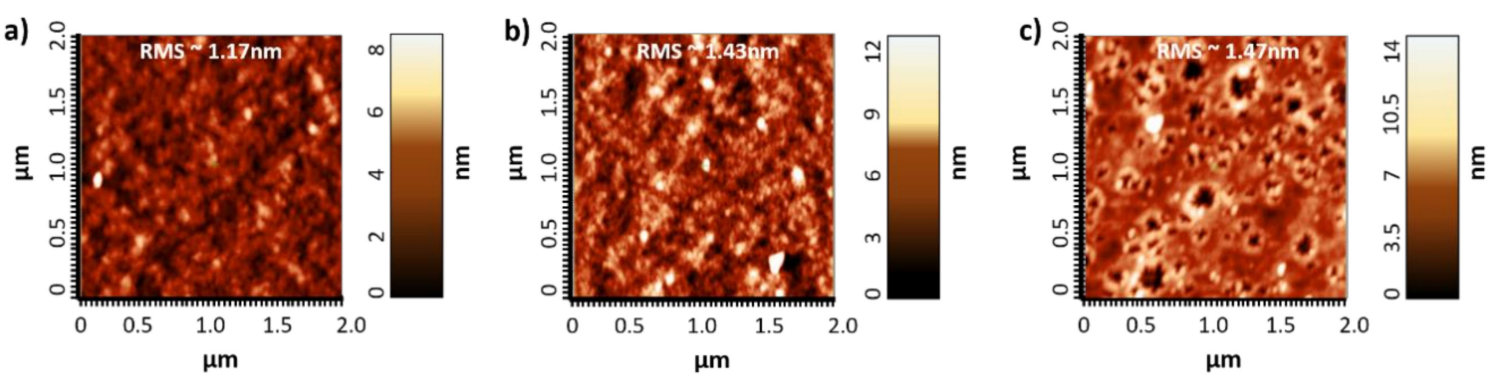

Figure 5. Atomic force microscopy (AFM) images of thin films. (a) PTB7-Th and ITIC blend, (b) PFN upon PTB7-Th and ITIC blend, (c) NDI-OH upon PTB7-Th and ITIC blend.

\section{Conclusions}

In summary, we have designed and synthesized an n-type self-doped naphthalene diimide ionene polymer (NDI-OH), containing the ion moiety in the backbone. NDI-OH has all the excellent chemical and electronic features: PFN, NDI-OH has good solubility in alcoholic solvents, it is less reactive than $\mathrm{Ca}$, it has suitable HOMO-LUMO energy levels, and it is prone to thickness insensitivity when used as CIL. EPR measurements indicate self-doping properties of NDI-OH, which are enhanced upon annealing. Importantly, the interaction between NDI-OH and the acceptor component in NFA PSC is more evident, demonstrated by photoluminescence quenching. Indeed, the photovoltaic performances of NFA PSCs containing NDI-OH as cathode interlayer have comparable efficiencies with those containing the optimized PFN and the evaporated $\mathrm{Ca}$, while for the FA the device performances increased with respect to no IL. Moreover, the NDI-OH demonstrates a good 
tolerance to interlayer thicknesses, which is an advantage to envisage the scaling-up to industrial application for OSCs.

Supplementary Materials: The following are available online at https://www.mdpi.com/1996 -1073/14/2/454/s1, Figure S1: Cyclic voltammetry of NDI-OH in ACN (potential vs. Ag/AgCl); Figure S2: FTIR spectra of NDI-OH films without and with annealing; Figure S3: Steady state photoluminescence for PC71BM/ILs film (a); excitation wavelength $500 \mathrm{~nm}$. Steady state photoluminescence for ITIC/ILs film (b); excitation wavelength $700 \mathrm{~nm}$; Figure S4: J-V curves in dark conditions of the devices. FA-based (left) and NFA-based PSCs (right); Table S1. Thicknesses are an average out of 4 measurements of the glass/NDI-OH spin coated samples. Figure of merit values are an average out of 6 pixels each thickness.

Author Contributions: Conceptualization, R.S., M.P., E.K., S.L.; synthesis of NDI-OH A.A.-E., E.K.; solar cells fabrication and analysis, R.S.; EPR and NMR analysis, A.A.-E., H.Š.; AFM images, G.S.; writing—original draft preparation, R.S., E.K.; writing—review and editing, R.S., M.P., E.K., S.L., A.A.-E., H.Š.; supervision, S.L.; All authors have read and agreed to the published version of the manuscript.

Funding: This work was performed during the implementation of the project Building-up Centre for advanced materials application of the Slovak Academy of Sciences, ITMS project code 313021T081 supported by the Research \& Innovation Operational Program funded by the ERDF.

Institutional Review Board Statement: Not applicable.

Informed Consent Statement: Not applicable.

Data Availability Statement: The data presented in this study are available in the article and Supporting Information.

Acknowledgments: This work has been supported by Slovak Grant Agency for Science contract APVV 17-0352, VEGA No.: 2/0161/17.

Conflicts of Interest: The authors declare no conflict of interest. The funders had no role in the design of the study; in the collection, analyses, or interpretation of data; in the writing of the manuscript, or in the decision to publish the results.

\section{References}

1. Yu, G.; Gao, J.; Hummelen, J.C.; Wudl, F.; Heeger, A.J. Polymer photovoltaic cells: Enhanced efficiencies via a network of internal donor-acceptor heterojunctions. Science 1995, 270, 1789-1791. [CrossRef]

2. Ye, L.; Xiong, Y.; Zhang, Q.; Li, S.; Wang, C.; Jiang, Z.; Hou, J.; You, W.; Ade, H. Surpassing $10 \%$ efficiency benchmark for nonfullerene organic solar cells by scalable coating in air from single nonhalogenated solvent. Adv. Mater. 2018, 30, 1705485. [CrossRef] [PubMed]

3. Song, W.; Fan, X.; Xu, B.; Yan, F.; Cui, H.; Wei, Q.; Peng, R.; Hong, L.; Huang, J.; Ge, Z. Solar Cells: Surpassing 10\% Efficiency Benchmark for Nonfullerene Organic Solar Cells by Scalable Coating in Air from Single Nonhalogenated Solvent (Adv. Mater. 8/2018). Adv. Mater. 2018, 30, 1800075. [CrossRef] [PubMed]

4. Kaltenbrunner, M.; White, M.S.; Głowacki, E.D.; Sekitani, T.; Someya, T.; Sariciftci, N.S.; Bauer, S. Ultrathin and lightweight organic solar cells with high flexibility. Nat. Commun. 2012, 3, 770. [CrossRef]

5. Wadsworth, A.; Moser, M.; Marks, A.; Little, M.S.; Gasparini, N.; Brabec, C.J.; Baran, D.; McCulloch, I. Critical review of the molecular design progress in non-fullerene electron acceptors towards commercially viable organic solar cells. Chem. Soc. Rev. 2019, 48, 1596. [CrossRef]

6. Tai, Q.; Yan, F. Emerging semitransparent solar cells: Materials and device design. Adv. Mater. 2017, 29, 1700192. [CrossRef]

7. Liu, Q.; Jiang, Y.; Jin, K.; Qin, J.; Xu, J.; Li, W.; Xiong, J.; Liu, J.; Xiao, Z.; Sun, K.; et al. 18\% Efficiency organic solar cells. Sci. Bull. 2020, 65, 272-275. [CrossRef]

8. Liao, C.Y.; Chen, Y.; Lee, C.C.; Wang, G.; Teng, N.W.; Lee, C.H.; Li, W.L.; Chen, Y.K.; Li, C.H.; Ho, H.L.; et al. Processing Strategies for an Organic Photovoltaic Module with over 10\% Efficiency. Joule 2020, 4, 189-206. [CrossRef]

9. Zhou, Y.; Kurosawa, T.; Ma, W.; Guo, Y.; Fang, L.; Vandewal, K.; Diao, Y.; Wang, C.; Yan, Q.; Reinspach, J. High performance all-polymer solar cell via polymer side-chain engineering. Adv. Mater. 2014, 26, 3767-3772. [CrossRef]

10. Luo, Z.; Bin, H.; Liu, T.; Zhang, Z.G.; Yang, Y.; Zhong, C.; Qiu, B.; Li, G.; Gao, W.; Xie, D. Fine-tuning of molecular packing and energy level through methyl substitution enabling excellent small molecule acceptors for non-fullerene polymer solar cells with efficiency up to $12.54 \%$. Adv. Mater. 2018, 30, 1706124. [CrossRef] 
11. Xu, X.; Bi, Z.; Ma, W.; Wang, Z.; Choy, W.C.H.; Wu, W.; Zhang, G.; Li, Y.; Peng, Q. Highly efficient ternary-blend polymer solar cells enabled by a nonfullerene acceptor and two polymer donors with a broad composition tolerance. Adv. Mater. 2017, 29, 1704271. [CrossRef] [PubMed]

12. Jiang, W.; Yu, R.; Liu, Z.; Peng, R.; Mi, D.; Hong, L.; Wei, Q.; Hou, J.; Kuang, Y.; Ge, Z. Ternary nonfullerene polymer solar cells with $12.16 \%$ efficiency by introducing one acceptor with cascading energy level and complementary absorption. Adv. Mater. 2018, 30, 1703005. [CrossRef] [PubMed]

13. He, C.; Zhong, C.; Wu, H.; Yang, R.; Yang, W.; Huang, F.; Bazan, G.C.; Cao, Y.J. Origin of the enhanced open-circuit voltage in polymer solar cells via interfacial modification using conjugated polyelectrolytes. Mater. Chem. 2010, 20, 2617-2622. [CrossRef]

14. Cheng, Y.J.; Hsieh, C.H.; He, Y.; Hsu, C.S.; Li, Y. Combination of indene-C60 bis-adduct and cross-linked fullerene interlayer leading to highly efficient inverted polymer solar cells. J. Am. Chem. Soc. 2010, 132, 17381-17383. [CrossRef]

15. Liao, S.H.; Jhuo, H.J.; Yeh, P.N.; Cheng, Y.S.; Li, Y.L.; Lee, Y.H.; Sharma, S.; Chen, S.A. Single junction inverted polymer solar cell reaching power conversion efficiency $10.31 \%$ by employing dual-doped zinc oxide nano-film as cathode interlayer. Sci. Rep. 2015, 4, 6813. [CrossRef]

16. Jeong, M.; Jin, H.C.; Moon, D.K.; Kim, I.H. Small-Molecule Electrolyte: Simple Approach to Overcome Thickness Tolerance of Interlayer without Sacrificing the Performances of Polymer Solar Cells (Adv. Mater. Interfaces 18/2019). Adv. Mater. Interfaces 2019, 6, 1900797. [CrossRef]

17. Hu, L.; Liu, Y.; Mao, L.; Xiong, S.; Sun, L.; Zhao, N.; Qin, F.; Jianga, Y.; Zhou, Y. Chemical reaction between an ITIC electron acceptor and an amine-containing interfacial layer in non-fullerene solar cells. J. Mater. Chem. A 2018, 6, 2273-2278. [CrossRef]

18. Hu, L.; Xiong, S.; Wang, W.; Sun, L.; Qin, F.; Zhou, Y. Influence of Substituent Groups on Chemical Reactivity Kinetics of Nonfullerene Acceptors. J. Phys. Chem. C 2020, 124, 2307-2312. [CrossRef]

19. Sorrentino, R.; Kozma, E.; Luzzati, S.; Po, R. Interlayers for non-fullerene based polymer solar cells: Distinctive features and challenges. Energy Environ. Sci. 2021. [CrossRef]

20. Sun, K.; Zhang, S.; Li, P.; Xia, Y.; Zhang, X.; Du, D.; Isikgor, F.H.; Ouyang, J. Review on application of PEDOTs and PEDOT: PSS in energy conversion and storage devices. J. Mater. Sci. Mater. Electron. 2015, 26, 4438-4462. [CrossRef]

21. Ratcliff, E.L.; Zacher, B.; Armstrong, N.R. Selective interlayers and contacts in organic photovoltaic cells. J. Phys. Chem. Lett. 2011, 2, 1337-1350. [CrossRef] [PubMed]

22. Salim, T.; Yin, Z.; Sun, S.; Huang, X.; Zhang, H.; Lam, Y.M. Solution-processed nanocrystalline $\mathrm{TiO}_{2}$ buffer layer used for improving the performance of organic photovoltaics. Appl. Mater. Interfaces 2011, 3, 1063-1067. [CrossRef] [PubMed]

23. Stubhan, T.; Oh, H.; Pinna, L.; Krantz, J.; Litzov, I.; Brabec, C.J. Inverted organic solar cells using a solution processed aluminumdoped zinc oxide buffer layer. Org. Electron. 2011, 12, 1539-1543. [CrossRef]

24. Seo, J.H.; Gutacker, A.; Sun, Y.; Wu, H.; Huang, F.; Cao, Y.; Scherf, U.; Heeger, A.J.; Bazan, G.C. Improved high-efficiency organic solar cells via incorporation of a conjugated polyelectrolyte interlayer. J. Am. Chem. Soc. 2011, 133, 8416-8419. [CrossRef] [PubMed]

25. Mai, C.K.; Schlitz, R.A.; Su, G.M.; Spitzer, D.; Wang, X.; Fronk, S.L.; Cahill, D.G.; Chabinyc, M.L.; Bazan, G.C. Side-chain effects on the conductivity, morphology, and thermoelectric properties of self-doped narrow-band-gap conjugated polyelectrolytes. J. Am. Chem. Soc. 2014, 136, 13478-13481. [CrossRef]

26. He, Z.; Zhong, C.; Huang, X.; Wong, W.Y.; Wu, H.; Chen, L.; Su, S.; Cao, Y. Simultaneous enhancement of open-circuit voltage, short-circuit current density, and fill factor in polymer solar cells. Adv. Mater. 2011, 23, 4636-4643. [CrossRef]

27. Yang, T.; Wang, M.; Duan, C.; Hu, X.; Huang, L.; Peng, J.; Huang, F.; Gong, X. Inverted polymer solar cells with $8.4 \%$ efficiency by conjugated polyelectrolyte. Energy Environ. Sci. 2012, 5, 8208-8214. [CrossRef]

28. Zhou, Y.; Fuentes-Hernandez, C.; Shim, J.; Meyer, J.; Giordano, A.J.; Li, H.; Winget, P.; Papadopoulos, T.; Cheun, H.; Kim, J.; et al. A universal method to produce low-work function electrodes for organic electronics. Science 2012, 336, 327-332. [CrossRef]

29. Peng, Z.; Zhang, Y.; Xia, Y.; Xiong, K.; Cai, C.; Xia, L.; Hu, Z.; Zhang Huang, F.; Hou, L. One-step coating inverted polymer solar cells using a conjugated polymer as an electron extraction additive. J. Mater. Chem. A 2015, 3, 20500-20507. [CrossRef]

30. Yin, Z.; Wei, J.; Zheng, Q. Interfacial materials for organic solar cells: Recent advances and perspectives. Adv. Sci. 2016, 3, 1500362. [CrossRef]

31. Yang, B.; Zhang, S.; Li, S.; Yao, H.; Li, W.; Hou, J. A Self-Organized Poly (vinylpyrrolidone)-Based Cathode Interlayer in Inverted Fullerene-Free Organic Solar Cells. Adv. Mater. 2019, 31, 1804657. [CrossRef] [PubMed]

32. Hu, Z.; Xu, R.; Dong, S.; Lin, K.; Liu, J.; Huang, F.; Cao, Y. Quaternisation-polymerized N-type polyelectrolytes: Synthesis, characterisation and application in high-performance polymer solar cells. Mater. Horiz. 2017, 4, 88-97. [CrossRef]

33. Wu, Z.; Sheng, C.; Dong, S.; Jiang, X.-F.; Siping, W.; Wu, H.; Yip, H.L.; Huang, F.; Cao, Y. n-Type water/alcohol-soluble naphthalene diimide-based conjugated polymers for high-performance polymer solar cells. J. Am. Chem. Soc. 2016, 138, 2004-2013. [CrossRef] [PubMed]

34. Hu, Z.; Chen, Z.; Zhang, K.; Zheng, N.; Xie, R.; Liu, X.; Yang, X.; Huang, F.; Cao, Y. Self-Doped n-Type Water/Alcohol SolubleConjugated Polymers with Tailored Backbones and Polar Groups for Highly Efficient Polymer Solar Cells. Solar RRL 2017, 1, 61700055. [CrossRef]

35. Kang, Q.; Ye, L.; Xu, B.; An, C.; Stuard, S.J.; Zhang, S.; Yao, H.; Ade, H.; Hou, J. A printable organic cathode interlayer enables over $13 \%$ efficiency for $1-\mathrm{cm}^{2}$ organic solar cells. Joule 2019, 3, 227-239. [CrossRef] 
36. Liu, M.; Fan, P.; Hu, Q.; Russell, T.P.; Liu, Y. Aphthalene-Diimide-Based Ionenes as Universal Interlayers for Efficient Organic Solar Cells. Angew. Chem. Int. Ed. 2020, 59, 18131-18135. [CrossRef]

37. William, S.R.; Long, T.E. Recent advances in the synthesis and structure-property relationships of ammonium ionenes. Prog. Polym. Sci. 2009, 34, 762-782. [CrossRef]

38. Andric, G.; Boas, J.F.; Bond, A.M.; Fallon, G.D.; Ghiggino, K.P.; Hogan, C.F.; Hutchison, J.A.; Lee, M.A.; Langford, S.J.; Pilbrow, J.R.; et al. Spectroscopy of naphthalene diimides and their anion radicals. Aust. J. Chem. 2004, 57, 1011-1019. [CrossRef]

39. Reilly, T.H., III; Hains, A.W.; Chen, H.Y.; Gregg, B.A. A Self-Doping, $\mathrm{O}_{2}$-Stable, n-Type Interfacial Layer for Organic Electronics. Adv. Energy Mater. 2012, 2, 455-460. [CrossRef]

40. Sun, C.; Wu, Z.; Hu, Z.; Xiao, J.; Zhao, W.; Li, H.-W.; Li, Q.-Y.; Tsang, S.-W.; Xu, Y.-X.; Zhang, K.; et al. Interface design for high-efficiency non-fullerene polymer solar cells. Energy Environ. Sci. 2017, 10, 1784-1791. [CrossRef]

41. Luo, J.; Wu, H.; He, C.; Li, A.; Yang, W.; Cao, Y. Enhanced open-circuit voltage in polymer solar cells. Appl. Phys. Lett. 2009, 95, 043301.

42. Bao, Q.; Liu, X.; Wang, E.; Fang, J.; Gao, E.; Braun, S.; Fahlman, M. Regular energetics at conjugated electrolyte/electrode modifier for organic electronics and their implications on design rules. Adv. Mater. Interfaces 2015, 2, 500204. [CrossRef]

43. Bi, S.; Leng, X.; Li, Y.; Zheng, Z.; Zhang, X.; Zhang, Y.; Zhou, H. Interfacial modification in organic and perovskite solar cells. Adv. Mater. 2019, 31, 1805708. [CrossRef] [PubMed] 